\title{
- JAKOŚĆ ŻYCIA CHORYCH PO WSZCZEPIENIU STYMULATORA SERCA
}

\author{
QUALITY OF LIFE OF PATIENTS WITH PEACEMAKERS \\ Kornelia Kaczyńska ${ }^{1}$, Józefa Czarnecka ${ }^{2}$, Ewa Kobos ${ }^{3}$, Zofia Sienkiewicz ${ }^{3}$ \\ ${ }^{1}$ absolwentka pielęgniarstwa \\ Warszawski Uniwersytet Medyczny \\ ${ }^{2}$ Zakład Podstaw Pielęgniarstwa \\ Warszawski Uniwersytet Medyczny \\ ${ }^{3}$ Zakład Pielęgniarstwa Społecznego \\ Warszawski Uniwersytet Medyczny
}

DOI: https://doi.org/10.20883/pielpol.2017.63

\section{STRESZCZENIE}

Wstęp. Akceptacja stanu zdrowia pacjenta z rozrusznikiem serca bądź jej brak to ważne czynniki mające wpływ na ocenę jakości życia.

Cel. Celem pracy była ocena jakości życia chorych po wszczepieniu stymulatora serca.

Materiał i metody. Badaniem objęto 72 pacjentów po zabiegu wszczepienia stymulatora serca. W celu zebrania materiału badawczego wykorzystano autorski kwestionariusz, w którym chorzy po zabiegu implantacji stymulatora serca dokonali subiektywnej oceny różnych aspektów życia. Analizę wyników przeprowadzono za pomocą programu statystycznego SPSS Statistics. Wyniki. Badania dowiodły, że jakość życia dla 38,9\% chorych po wszczepieniu stymulatora uległa znacznej poprawie. Sam zabieg nie zmienił życia zawodowego połowy $(50,0 \%)$ badanych, $41,7 \%$ musiało ograniczyć życie zawodowe. Życie kulturowe poprawiło się u $33,3 \%$ badanych. Niemal wszyscy oceniali obecny stan zdrowia jako dobry $(91,7 \%)$. Tylko według $8,3 \%$ był on zły. Wsparcie ze strony rodziny i przyjaciół otrzymali prawie wszyscy badani $(94,4 \%)$. Stwierdzono wysoce istotną statystycznie korelację między wiekiem pacjentów a odczuwanym bólem, który zakłócał badanym funkcjonowanie $w$ życiu zawodowym $(p=0,003)$ i codziennym ( $p=004)$.

Wnioski.

1. U pacjentów po wszczepieniu stymulatora serca istnieje zależność między wiekiem a jakością życia po zabiegu. Ból częściej zakłócał funkcjonowanie w życiu zawodowym i codziennym osobom młodszym niż osobom starszym.

2. Wszczepienie stymulatora wpłynęło pozytywnie na życie zawodowe i kulturowe ankietowanych.

3. Obecny stan swojego zdrowia chorzy oceniali jako dobry.

4. Ogólna jakość życia ankietowanych uległa poprawie.

SŁOWA KLUCZOWE: jakość, stymulator serca, wszczepienie.

\section{Wstęp}

Stymulacja serca stała się skuteczną procedurą zapobiegania zaburzeniom rytmu i przewodnictwa w

\section{ABSTRACT}

Introduction. Patient's acceptance of his health condition, or lack of it, is a very important factor influencing a quality of life. Aim. The aim of this research was evaluation of the quality of life of patients with peacemakers.

Material and methods. 72 patients who underwent peacemaker grafting surgery took part in the research. In order to collect the research data author's owes questionnaire was used. It asked respondents, who had peacemaker implanted, to subjectively evaluate different aspects of life. An analysis of the results was conducted using the SPSS Statistics programme.

Results. Research proved that for $38.9 \%$ of patients quality of life was significantly improved after the implantation surgery. The procedure itself did not have any impact on employment activities for half $(50 \%)$ of the respondents, while $41.7 \%$ had to reduce them. Cultural aspect of life was improved in $33.3 \%$ of respondents. Nearly all of them evaluated their health as good ( $91.7 \%)$. Only $8.3 \%$ thought it was bad. Support from family and friends was received by nearly all of the respondents (94.4\%). There was statistically very important correlation between the age of a patient and pain which interfere with his functioning at a workplace $(p=0.003)$ and everyday life $(p=0.004)$.

Results.

1. There is a correlation between the age of a patient with the peacemaker and quality of life after the procedure. Pain more often influenced employment activities and everyday life of younger patients when compared with the older ones.

2. Peacemaker implantation had positive impact on respondents' employment and everyday life.

3. Patients evaluated their current health as good.

4. Overall, respondents' quality of life has improved.

KEYWORDS: quality, peacemaker, implantation.

mięśniu sercowym. Wszczepienie stymulatora jest możliwe zarówno u osób młodych, jak i starszych, po uprzednim zebraniu informacji o chorym i pomyślnym 
zakwalifikowaniu go do zabiegu. Wskazaniem do implantacji stymulatora serca jest spełnienie wymogów określonych przez standardy Polskiego Towarzystwa Kardiologicznego oraz European Society of Cardiology [1]. Wszczepienie stymulatora stanowi początek innego życia, w którym chory musi dokonać pewnych modyfikacji, ulepszeń, akceptacji choroby przewlekłej, aby móc funkcjonować i nadal cieszyć się życiem, jakie prowadził dotychczas. Przystosowanie się do choroby przewlekłej będzie zmniejszało nasilenie negatywnych emocji, a tym samym będzie powiększało poczucie własnej wartości. Osoba z układem stymulującym ma możliwość powrotu do pełnej aktywności życiowej i zawodowej, nie musi rezygnować z czynnej pracy czy zmieniać wykonywanego zawodu [2]. Ogólnie zakres obciążeń będzie indywidualny dla każdego chorego. Wiele zależy od wieku pacjenta oraz stopnia zaawansowania uszkodzenia mięśnia serca. To właśnie te czynniki, a nie sam fakt wszczepienia urządzenia mogą powodować pewne ograniczenia. Nie przeszkadza to jednak w normalnym funkcjonowaniu w życiu, oddaniu się swemu hobby, jak również podjęciu ponownie aktywności fizycznej i seksualnej [3]. Ważnym czynnikiem mającym wpływ na satysfakcję z życia jest więc akceptacja choroby przewlekłej.

\section{Cel pracy}

Celem pracy była ocena jakości życia chorych po wszczepieniu stymulatora serca.

\section{Materiał i metody}

Badania przeprowadzone były w kwietniu 2016 roku. Grupą badaną byli pacjenci po zabiegu wszczepienia stymulatora serca w szpitalu klinicznym w Warszawie. W badaniu wzięło udział 72 pacjentów, z czego ponad połowę stanowiły kobiety (55,6\%). Do przeprowadzenia badań posłużono się ankietą własnego autorstwa. Ankieta zawierała 34 pytania jednokrotnego wyboru. Pytania dotyczyły strefy psychicznej, fizycznej, zawodowej, kulturowej i życia codziennego oraz danych demograficznych. W obrębie tych zagadnień pytano respondenta o jakość życia przed zabiegiem wszczepienia rozrusznika i po tym zabiegu. Analizę wyników przeprowadzono za pomocą programu statystycznego SPSS Statistics. Korelacje pomiędzy zmiennymi przeanalizowano za pomocą testu chi-kwadrat. Za krytyczny przyjęto poziom istotności $p$ $<0,05$.

\section{Wyniki}

Najliczniejszą grupą badaną byli pacjenci w wieku 60-80 lat (40,3\%). Mniej liczna $(23,6 \%)$ była grupa z przedziału wiekowego 40-60 lat. Najmniejszą grupę (po 18\%) stanowiły osoby w przedziale wieku 20-40 lat i powyżej 80 lat. Z wykształceniem średnim było 40,3\% badanych, wyższym - 33,3\%, zawodowym - 26,4\%.
Ponad połowa (52,8\%) pacjentów pochodziła z miasta. Tylko 31,9\% badanych pracowało zawodowo. Dla pozostałych źródłem utrzymania była renta $(22,3 \%)$ lub emerytura (45,8\%). Dla $77,8 \%$ badanych było to kolejne wszczepienie stymulatora serca (dla 46,5\% - drugie, zaś dla 8,9\% - trzecie lub więcej). Jedna trzecia badanych całkowicie akceptowała swoją sytuację zdrowotną, a ponad połowa $(54,2 \%)$ akceptowała ją w stopniu umiarkowanym. Nie akceptowało swojej sytuacji zdrowotnej $12,5 \%$ badanych.

\section{Ból}

Po implantacji stymulatora $75 \%$ badanych nie odczuwało bólu. Ponad połowie pacjentów ból nie przeszkadzał w funkcjonowaniu w życiu zawodowym (63,9\%), codziennym $(61,1 \%)$, towarzyskim $(55,6 \%)$. Czasami przeszkadzał w życiu zawodowym (23,6\%), codziennym (25,0\%), towarzyskim (18,1\%). Ból zdecydowanie $(2,8 \%)$ i często $(9,7 \%)$ przeszkadzał w życiu zawodowym pacjentów, a także w życiu codziennym (1,4\% i 12,5\%) i towarzyskim (11,0\% i 15,3\%).

\section{Wpływ implantacji symulatora na ogólne życie chorych}

Pozytywny wpływ stymulatora na ogólne życie odczuwało $73,7 \%$ badanych. Zdecydowanie negatywny wpływ wskazało 6,9\% badanych (Rycina 1). Lęku o zdrowie nie odczuwało $70,8 \%$ badanych. W badanej grupie $71,1 \%$ respondentów nie odczuwało zmęczenia i wyczerpania po wszczepieniu stymulatora. Występowały one natomiast u 28,9\% badanych. Objawów depresji nie miało $84,8 \%$ badanych. Takie objawy pojawiły się u 15,2\% badanych. Z zaburzeniami emocjonalnymi po zabiegu borykało się $28,8 \%$ badanych. W ocenie $38,9 \%$ badanych życie emocjonalne po zabiegu poprawiło się. Ponad połowa badanych $(69,5 \%)$ uznała, że ich stan zdrowia po zabiegu jest lepszy niż przed (Rycina 2). Większość badanych $(76,4 \%)$ uważała, że ich życie zostało ograniczone w jakiś sposób po wszczepieniu stymulatora. Obecny stan zdrowia badani ocenili jako: dobry $(23,7 \%)$, bardzo dobry $(33,3 \%)$, zadowalający $(34,7 \%)$ i zły $(8,3 \%)$.

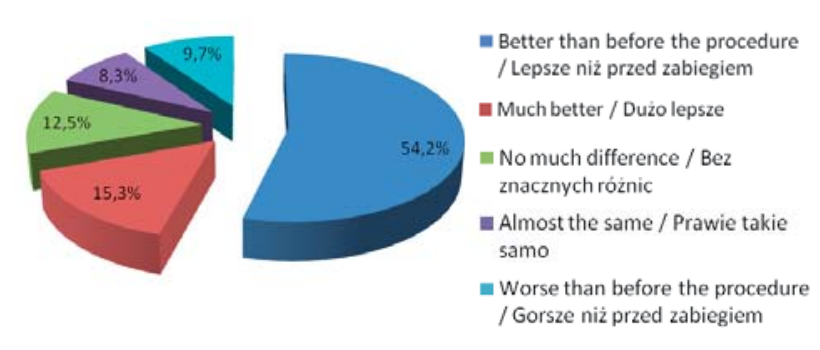

Rycina 1. Wpływ wszczepienia rozrusznika na ogólne życie chorych Figure 1. Evaluation of current health in comparison to health before the procedure

Źródło: badania własne

Source: author's own materials 


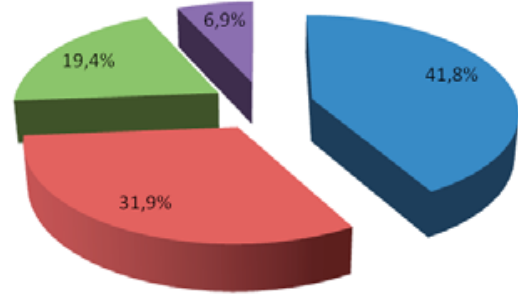

- Rather positive / Raczej pozytywnie

Definitely positive/ Zdecydowanie pozytywnie

- Rather negative / Raczej negatywnie

- Definitely negative / Zdecydowanie negatywnie

Rycina 2. Obecna ocena stanu zdrowia w porównaniu ze zdrowiem przed zabiegiem

Figure 2. Impact of peacemaker implantation on patients' overall health Źródło: badania własne

Source: author's own materials

\section{Wsparcie rodziny i bliskich}

Prawie wszyscy badani $(94,4 \%)$ deklarowali poczucie wsparcia i akceptacji ze strony rodziny i znajomych. Tylko $5,6 \%$ badanych nie czuło wsparcia i akceptacji.

\section{Aktywność fizyczna}

Według 77,8\% badanych aktywność fizyczna nie uległa zmianie $\mathrm{i}$ jest na takim samym poziomie jak przed zabiegiem, natomiast w przypadku 22,2\% badanych aktywność ta zmniejszyła się. Połowa badanych nie zmieniła swojego życia zawodowego, a 41,7\% musiało ograniczyć życie zawodowe lub z niego zrezygnować (8,3\%) (Rycina 3). Życie kulturowe poprawiło się według jednej trzeciej badanych (Rycina 4).
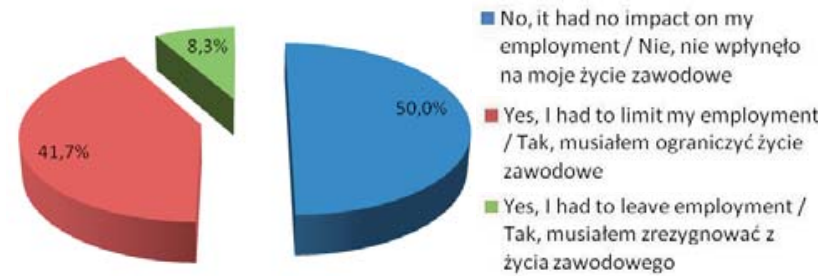

Rycina 3. Stymulator a życie zawodowe Figure 3. Peacemaker vs employment activities

Źródło: badania własne

Source: author's own materials

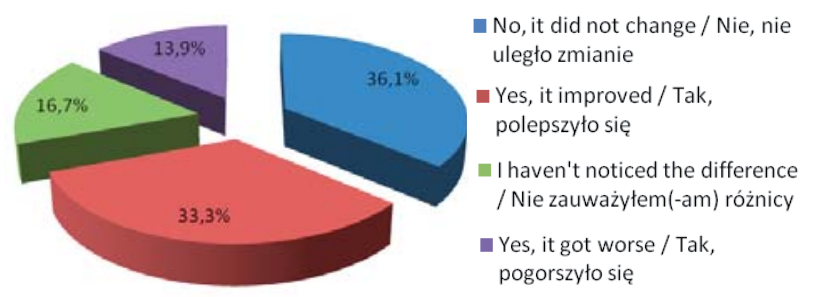

Rycina 4. Wpływ stymulatora na życie kulturowe Figure 4. Peacemaker's impact on patients' cultural life Źródło: badania własne Source: author's own materials

\section{Zależności między dwoma zmiennymi jakościowymi}

Osoby młodsze częściej niż osoby starsze wskazywały, że odczuwają ból, który zakłóca im funkcjonowanie w życiu zawodowym. W tym przypadku wystąpiła wysoce istotna statystycznie zależność na poziomie $p=0,003$ (Tabela 1). Stwierdzono również wysoce istotną korelację między odczuwanym bólem, który zakłócał chorym funkcjonowanie w życiu codziennym ( $p=004)$, a wiekiem. Wraz z wiekiem odczuwany poziom bólu malał (Tabela 2).

Tabela 1. Zależność pomiędzy wiekiem a predyspozycją do zakłócania życia zawodowego/codziennego przez ból

Table 1. Correlation between the age of a patient and a predisposition of their employment being influenced by pain

\begin{tabular}{|c|c|c|c|c|c|}
\hline \multirow[b]{2}{*}{$\begin{array}{c}\text { Czy odczuwalny ból zakłócał } \\
\text { funkcjonowanie w życiu } \\
\text { zawodowym?Did the expe- } \\
\text { rienced pain interfere with } \\
\text { the activities of your employ- } \\
\text { ment? }\end{array}$} & \multicolumn{4}{|c|}{ Wiek/Age } & \multirow[b]{2}{*}{$\begin{array}{c}\text { Ogółem } \\
\text { Total }\end{array}$} \\
\hline & 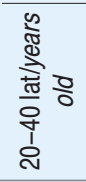 & 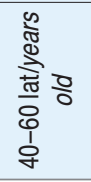 & 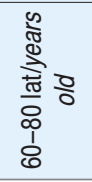 & 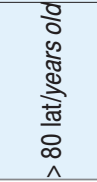 & \\
\hline \multirow{2}{*}{ Tak/Yes } & 9 & 7 & 10 & 0 & 26 \\
\hline & $69,2 \%$ & $41,2 \%$ & $34,5 \%$ &, $0 \%$ & $36,1 \%$ \\
\hline \multirow{2}{*}{$\mathrm{Nie} / \mathrm{No}$} & 4 & 10 & 19 & 13 & 46 \\
\hline & $30,8 \%$ & $58,8 \%$ & $65,5 \%$ & $100,0 \%$ & $63,9 \%$ \\
\hline \multirow[b]{2}{*}{ Ogółem/Total } & 13 & 17 & 29 & 13 & 72 \\
\hline & $100,0 \%$ & $100,0 \%$ & $100,0 \%$ & $100,0 \%$ & $100,0 \%$ \\
\hline \multicolumn{6}{|c|}{ chi-kwadrat $=13,751 ; p=0,003 /$ chi-square $=13.751 ; p=0.003$} \\
\hline
\end{tabular}

Źródło: badania własne

Source: author's own materials

Tabela 2. Zależność pomiędzy wiekiem a predyspozycją do zakłócenia życia codziennego przez ból

Table 2. Correlation between the age of a patient and a predisposition of their everyday life being influenced by pain

\begin{tabular}{|c|c|c|c|c|c|}
\hline \multirow{2}{*}{$\begin{array}{l}\text { Czy odczuwalny ból zakłócał } \\
\text { funkcjonowanie w życiu } \\
\text { codziennym?Did the expe- } \\
\text { rienced pain interfere with } \\
\text { your everyday life activities? }\end{array}$} & \multicolumn{4}{|c|}{ Wiek/Age } & \multirow[b]{2}{*}{$\begin{array}{l}\text { Ogó- } \\
\text { łem/ } \\
\text { Total }\end{array}$} \\
\hline & 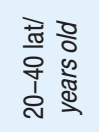 & 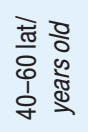 & 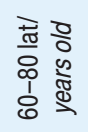 & 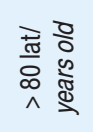 & \\
\hline \multirow{2}{*}{ Tak/Yes } & 9 & 7 & 12 & 0 & 28 \\
\hline & $69,2 \%$ & $41,2 \%$ & $41,4 \%$ &, $0 \%$ & $38,9 \%$ \\
\hline \multirow{2}{*}{ Nie/No } & 4 & 10 & 17 & 13 & 44 \\
\hline & $30,8 \%$ & $58,8 \%$ & $58,6 \%$ & $100,0 \%$ & $61,1 \%$ \\
\hline \multirow{2}{*}{ Ogółem/Total } & 13 & 17 & 29 & 13 & 72 \\
\hline & $100,0 \%$ & $100,0 \%$ & $100,0 \%$ & $100,0 \%$ & $100,0 \%$ \\
\hline \multicolumn{6}{|c|}{ chi-kwadrat=13,422; $p=0,004 /$ chi-square $=13.422 ; p=0.004$} \\
\hline
\end{tabular}

Źródło: badania własne

Source: author's own materials

\section{Dyskusja}

Dla wielu pacjentów z chorobami serca zabieg wszczepienia stymulatora stanowi jedyną szansę na poprawę jakości życia bądź nawet na samo przeżycie. Jednak to, 
czy ich życie faktycznie ulegnie poprawie, czy ich funkcjonowanie w ogólnym życiu nie zmieni się i czy będą zadowoleni z życia po zabiegu, w dużej mierze będzie zależało od edukacji zdrowotnej przed zabiegiem. Edukacja ta powinna być ukierunkowana na uświadomienie pacjentowi, że może on prowadzić normalne życie i być w pełni aktywny zawodowo i społecznie [4]. Ważną rolę w przystosowaniu się i akceptacji sytuacji zdrowotnej, w jakiej chory się znalazł, odgrywa wsparcie społeczne. Jest ono potrzebne każdemu człowiekowi w sytuacji dla niego trudnej. Stan zdrowia w dużym stopniu wpływa na ocenę jakości życia [5, 6].

W przeprowadzonych badaniach własnych pacjenci oceniali subiektywnie stan swojego zdrowia psychicznego, fizycznego, życia kulturowego, samodzielności w życiu codziennym, swojej relacji ze środowiskiem oraz niezależności od otoczenia. Porównując swoje badania z badaniami przeprowadzonymi przez Siwek i wsp. [7], stwierdzono, że jakość życia chorych uległa poprawie. Wszczepienie rozrusznika zdecydowanie nie wpłynęło na ich aktywność fizyczną (38,9\%) po zabiegu ani nie doszło do zmiany w życiu zawodowym (50\%), kulturowym $(36,1 \%)$ i codziennym (34,7\%). Według znacznej grupy badanych (43,1\%) wszczepienie rozrusznika poprawiło im życie emocjonalne. Ogólny stan swojego stanu zdrowia po zabiegu chorzy ocenili jako dobry, a sam zabieg nie miał znacznego wpływu na stan emocjonalny pacjentów. Wiek odgrywał ważną rolę. $Z$ badań wynika, że wraz $z$ wiekiem maleje jakość życia chorych.

Z badań prowadzonych przez Reczek i wsp. [8] wynika, że chorzy przystosowali się do funkcjonowania w życiu ze stymulatorem. W badaniach własnych również wykazano brak zmiany w aktywności zawodowej po zabiegu u połowy badanych.

Wyniki zarówno własnych badań, jak i badań de Barros i wsp. [9] dowodzą, że na jakość życia po wszczepieniu stymulatora ma wpływ wiek. Stwierdzono wysoce istotną zależność między bólem, który zakłócał chorym funkcjonowanie w życiu zawodowym i codziennym, a wiekiem, ze wskazaniem na osoby młodsze, które częściej uskarżały się na odczuwany ból niż osoby starsze. Analiza postaw, jakie przejawiają pacjenci wobec swojej choroby i leczenia, pozwoliła na ocenę poziomu jakości życia. Chorzy dostrzegają wiele korzyści z posiadania rozrusznika serca, mimo iż 76,4\% badanych uważa, że ich życie zostało w jakimś stopniu ograniczone. Duży wpływ na dostosowanie się do nowych warunków życia i dobrego samopoczucia badanych miało wsparcie ze strony rodziny i przyjaciół. Prawie wszyscy badani $(94,4 \%)$ otrzymali takie wsparcie. Przeprowadzone badania własne oraz badania prowadzone przez różnych badaczy wskazują na poprawę jakości życia u chorych po implantacji stymulatora serca.

\section{Wnioski}

1. U pacjentów po wszczepieniu stymulatora serca istnieje zależność między wiekiem a jakością życia po zabiegu. Ból częściej zakłócał funkcjonowanie w życiu zawodowym i codziennym osobom młodszym niż osobom starszym.

2. Wszczepienie stymulatora wpłynęło pozytywnie na życie zawodowe i kulturowe ankietowanych.

3. Obecny stan swojego zdrowia chorzy oceniali jako dobry.

4. Ogólna jakość życia ankietowanych uległa poprawie.

\section{Piśmiennictwo}

1. Wytyczne dotyczące stymulacji serca i resynchronizacji. Grupa Robocza Europejskiego Towarzystwa Kardiologicznego ds. stymulacji serca i resynchronizacji we współpracy z Europejskim Towarzystwem Rytmu Serca. Eur Heart J. 2007; 28: 2256-2295.

2. Dylewicz P, Jegier A, Piotrowicz R, Rudnicki S, Tylka J, Mazurek K, Przywarska I, Rybicki J, Zdrojewski T. Kompleksowa rehabilitacja kardiologiczna. Socjoekonomiczne aspekty rehabilitacji kardiologicznej. Folia Cardiol. 2004; 1: 42-45.

3. Młynarska A, Młynarski R, Korgul W. Zmiany jakości życia po 6 miesiącach od implantacji stymulatora serca. Pol Prz Kardiol. 2010; 2: 116-120.

4. Pająk J, Durmała J, Kargul W, Plewa M, Nowak Z. Rola fizjoterapii u pacjentów z implantowanym kardiostymulatorem. Fizjoter Pol. 2006; 6(3): 245-250.

5. Jakubowska-Winecka A, Włodarczyk D (red.). Psychologia w praktyce medycznej. Warszawa: PZWL; 2007. 97-107.

6. Szymczak J. Zaburzenia psychiczne chorego somatycznie. W: Borys B, Majkowicz M (red.). Psychologia w medycynie. Gdańsk: AM w Gdańsku; 2006. 364-379.

7. Siwek M, Topór M, Mika M. Jakość życia po wszczepieniu stymulatora serca w opinii pacjentów. Piel XXI w. 2012; 4: 109-115.

8. Reczek A, Stańczykiewicz-Kudła K, Brzostek T, Malinowska-Lipień I, Kawalec E. Jakość życia chorych po wszczepieniu stymulatora serca. Piel Chir Angiol. 2011; 2: 107-113.

9. Barros RT, Carvalho SM, Silva MA. Evaluation of patients quality of life aspects after cardiac pacemaker implantation. Braz J Cardiovasc Surg. 2014; 29: 37-44.

Artykuł przyjęty do redakcji: 15.09 .2016

Artykuł przyjęty do publikacji: 20.03.2017

Źródło finansowania: Praca nie jest finansowana z żadnego źródła. Konflikt interesów: Autorzy deklarują brak konfliktu interesów.

\author{
Adres do korespondencji: \\ Józefa Czarnecka \\ ul. Erazma Ciołka 27 \\ 01-445 Warszawa \\ tel.: 228360971 \\ e-mail: j.czarnecka@wp.pl \\ Zakład Podstaw Pielęgniarstwa \\ Warszawski Uniwersytet Medyczny
}

